\section{Policy Brief October 2016}

\begin{tabular}{l} 
About APPRO: \\
Afghanistan Public Policy Research \\
Organization (APPRO) is an indepen- \\
dent social research organization with \\
a mandate to promote social and \\
policy learning to benefit develop- \\
ment and reconstruction efforts in \\
Afghanistan and other less devel- \\
oped countries through conducting \\
applied research, monitoring and \\
evaluation, and training and men- \\
toring. APPRO is registered with the \\
Ministry of Economy in Afghanistan \\
as a non-profit, non-government or- \\
ganization. APPRO is headquartered \\
in Kabul, Afghanistan, with offices in \\
Mazar-e Shrif (north), Herat (west), \\
Kandahar (south), Jalalabad (east), \\
and Bamyan (center). APPRO is also \\
the founding organization of APPRO- \\
Europe, registered in Belgium. \\
\hline
\end{tabular}

Contact us:

www.appro.org.af

Email: mail@appro.org.af

Tel: +93 700053081

www.appro-europe.net Email: mail@appro-europe.net Tel: +3228953601

Fax: +32 28953602

This and other publications by APPRO may be downloaded from:

http://appro.org.af/briefs/

\title{
Localization of NAP 1325
}

\section{Background}

Adopted on October 31, 2000, UNSCR 1325 is aimed at addressing the disproportionate and unique impact of armed conflict on women. UNSCR 1325 was followed by six additional Security Council Resolutions in subsequent years, providing further guidance regarding how women can and should participate in all aspects of conflict prevention and resolution, peace negotiations, peace-building, and peace-keeping. All United Nations' member states are committed to developing National Action Plans for implementing UNSCR 1325 and subsequent resolutions.

Afghanistan's NAP 1325 holds two broad objectives: gender balancing and gender mainstreaming. Gender balancing emphasizes the equal rights of men and women to participate in peace and security processes, and leadership. Gender mainstreaming draws attention to the fact that rules, regulations and policies have different impacts for men and women, with women often faring worse than men.

A better understanding of gender relations and the very different impacts of conflict and policies on men and women can enhance the quality and impact of policy objectives and policy outcomes. Afghanistan's NAP 1325 calls for the creation of mechanisms that enhance women's participation in negotiations for peace, politics, and decision-making at all levels. NAP 1325 also calls for mechanisms to prevent violence against women. Specific emphasis is placed on the situation of women and their needs in relief and recovery efforts. ${ }^{1}$

The findings and recommendations of this brief are drawn from research conducted in September-November 2015, using data collected from over 400 individuals (two thirds female, one third male) in 15 provinces. Secondary data were taken from Central Statistics Office, United Nations High Commissioner for Refugees,

Independent Elections Commission, Afghanistan Independent Human Rights Commission, provincial Departments of Women's Affairs, Family Response Units, and Afghan National Police in all provinces. A wide range of scientific literature, newspaper articles and reports by national and international governmental and non-governmental institutions was also consulted.

The findings are organized according to the four pillars of UNSCR 1325 : Participation, Prevention, Protection, and Relief and Recovery. The indicators under each pillar are broadly based on Afghanistan's NAP 1325 and APPRO's previous research, monitoring, and evaluation work in Afghanistan. 
“Gender balancing emphasizes the equal rights of men and women to participate in peace and security processes, and leadership. Gender mainstreaming draws attention to the fact that rules, regulations and policies have different impacts for men and women, with women often faring worse than men." - Afghanistan's NAP 1325

Women's participation in politics remains limited and fragile in all provinces despite important interventions since 2001 to increase participation and despite the high levels of participation in voting during the presidential elections of 2014.

\section{Participation}

\section{Participation Indicators:}

- Participation in Peace

- Participation in Politics

- Participation in Afghanistan National Security Forces

- Participation in Civil Service

- Participation in Decision-Making

Women's participation in politics remains limited and fragile in all provinces despite important interventions since 2001 to increase participation and despite the high levels of participation in voting during the presidential elections of 2014. Insecurity and conflict continue to act as the main impeding factors, compounded by traditional conservatism and patriarchy. Insecurity impedes the mobility of female members of Provincial Peace Councils, for example, who are already under pressure by their family members not to venture out of the home to participate in gathering and meetings.

\section{Women's participation in the civil service} and the labor market in general is adversely affected by traditional conservatism. In many provinces throughout the country, men generally do not approve of working with women in the same working space or have their female relatives work in shared spaces with other men. In all provinces, there is a need for more female police officers despite the fact that the vast majority of the communities throughout the country do not approve of women working in the police.

\section{Prevention}

\section{Prevention Indicators:}

- Types of Violence Against Women (VAW)

- Formal Methods of Preventing VAW

- Informal Methods of Preventing VAW

Violence against women increased in 2015 with nature and types of violence being described as more "dreadful" or "frightening" than before. ${ }^{2}$ Many believe that there is a direct relationship between violence against women and poverty and unemployment, compounded by conservatism and patriarchy and poor or no access to the formal judiciary. ${ }^{3}$

2 Hamidi, R. (2016): "A Look at the Causes of Violence Against Women", The Daily Afghanistan. Available at: http:// dailyafghanistan.com/opinion_detail.php?post_id=135610 (04-02-2016)

3 APPRO (2016): "Localization of NAP 1325: A 15-Province

\section{Protection}

\section{Protection Indicators:}

- Protection by the Formal Judiciary

- Protection by the Informal Judiciary

- Presence of and Access to Safe houses

The institutions in charge of protecting women, such as the formal judiciary and the police, are largely perceived to be corrupt and systematically discriminatory toward women. The Afghan National Police, Family Response Units, and numerous governmental organizations lack knowledge of the relevant laws such as the Elimination of Violence against Women (EVAW), National Action Plan for the Women of Afghanistan (NAPWA), and NAP 1325. In addition, deeply ingrained conservative social norms dissuade women from exercising their rights.

Reporting cases of violence against women often triggers social stigmatization, increases the risk of losing social and economic safety nets, and could lead to retaliation by perpetrators of violence. ${ }^{4}$ Because of these risks, most cases of domestic dispute are solved through community elders in a traditional judicial setting. Decisions made through traditional tribunals, however, are often unfair and discriminatory toward women.

\section{Relief and Recovery}

\section{Relief and Recovery Indicators}

- Provisions for Widows and Disabled

- Provisions for Female Internally Displaced People

- Reintegration Mechanisms for Women in Safe houses

- Reintegration Mechanisms for Women in Prisons

- Women's Access to Health and Education Services

Afghanistan is assumed to have one of the world's highest percentages of widows and disabled women. ${ }^{5}$ Although the law requires the Ministry of Labor, Social Affairs, Martyrs and Disabled and its provincial departments

Status Report". Available at: http://appro.org.af/localizationof-nap-1325-a-15-province-status-report/ (09-26-2016) 4 See also: USIP (2014) "Women's Access to Justice in Afghanistan". Available at: http://www.usip.org/publications/2014/07/17/womens-access-justice-in-afghanistan (04-02-2016)

5 Abrahams, J. (2014) "The War Widows of Afghanistan", Prospect Magazine. Available at: http://www.prospectmagazine. co.uk/blogs/jessica-abrahams/the-war-widows-of-afghanistan (02-27-2016) 
In terms of protection and prevention programming, much more needs to be done in temporary shelters to address basic food and shelter needs, while efforts to provide education for the children and adults, vocational training for women, and health services for women need to be intensified.

institutions in charge of protecting women, such as the formal judiciary and the police, are largely perceived to be corrupt and systematically discriminatory toward women.

Reporting cases of violence against women often triggers social stigmatization of the women, increases the risk of losing social and economic safety nets, and could lead to retaliation by the perpetrators of violence. to provide widows of war with a salary, there are serious concerns about corruption and nepotism in the process of dispensation, with funds being misappropriated and given to recipients not entitled to assistance.

Afghanistan has one of the highest numbers of conflict-induced displacement in the world. The protection of the internally displaced is outlined in the Internally Displaced Persons Policy as the mandate of the Ministry of Refugees and Repatriation. There is insufficient assistance by the ministry, however. UNHCR and several other international organizations continue provide most of the assistance. In terms of protection and prevention programming, much more needs to be done in temporary shelters to address basic food and shelter needs, while efforts to provide education for children and adults, vocational training for women, and health services for women need to be intensified.

All provinces generally lack reintegration programs and follow-ups on women residing in safe houses and prisons. Some provinces such as Helmand, Kandahar and Paktia have never had safe houses. Access to health services remains a challenge for women throughout the country, with health facilities being renowned for a lack of appropriate or sufficient medication, lack of sufficient female health personnel, and poor facilities.

\section{Recommendations}

\section{Government of Afghanistan}

- Continue the provision of trainings on gender equality, women's rights, EVAW law and UNSCR/NAP 1325 for men and women working in government entities, particularly the Afghan National Police, Family Response Units, and judges.

- Set up structures and procedures within the Afghan National Police, Family Response Units, and Departments of Women's Affairs in the provinces for better protection of women and promotion and implementation of preventive measures on violence against women.

- Maintain dialogue with traditional justice authorities to monitor the manners in which cases of violence against women are handled as the basis on which to devise preventive mechanisms including training and mentoring of traditional justice authorities on women's rights.
- Include religious institutions and religious leaders in efforts to combat violence against women.

- Set up supplementary structures for reintegration and protection of women released from houses and prisons.

- Revise and enhance the contents of trainings and workshops for female inmates to increase post-internment coping capacity after their release.

- Increase the number of female doctors by instance setting quotas at medical educational institutions.

- Increase the number of female judges and senior female justice officials by instituting quotas in legal educational institutions and increased appointment by governmental legal institutions of the number of female justice professionals, especially in the southern regions of the country.

\section{International Community}

- Devise innovative monitoring mechanisms to ensure the implementation of programs and relevant legislation pertaining to women's rights, particularly at the local and grassroots level.

- As much as possible, link ongoing and future programs to the various elements of the four pillars of NAP 1325 (Participation, Prevention, Protection, and Relief and Recovery)

- Increase the use of empirical evidence in program design

- Increase the inclusion of civil society organizations with rights-related mandates in all future women-centered programming.

\section{Civil Society and Non-Governmental Organizations}

- Campaign for removing gender bias in the formal judiciary, which has the responsibility to act as a deterrent to violators of women's rights.

- Through advocacy and active engagement, maintain and build on the momentum created by women's active interest and participation in the 2014 elections.

- Intensify advocacy for increased women's participation in the peace process

- Campaign for better delivery of provisions for widows and disabled women.

- Include men and boys in advocacy activities on women's rights. 